...... Pivarčiová, Barcík, Štefková, Škultéty: Investigation of Temperature Fields in the Air...

Elena Pivarčiová ${ }^{1}$ Štefan Barcik ${ }^{1}$, Jaroslava Štefková2, Emil Škultéty ${ }^{1}$

\title{
Investigation of Temperature Fields in the Air Environment above Wood Subjected to Thermal Degradation
}

\section{Ispitivanje temperaturnih polja u zraku iznad drva podvrgnutoga toplinskoj razgradnji}

\author{
Original scientific paper • Izvorni znanstveni rad \\ Received-prispjelo: 24. 4. 2018. \\ Accepted-prihvaćeno: 20. 11. 2019. \\ UDK: $630 * 812.14 ; 630 * 814.12$ \\ https://doi.org/10.5552/drvind.2019.1817
}

\begin{abstract}
The paper deals with the visualization of thermal fields above the sample body while observing thermal loading of wood. Via holographic interferometry, thermal fields were visualized in a non-contact manner and the values were recorded in 0, 3, 7 and 15 minutes or earlier in case of degradation. In real time, the ongoing processes were recorded in the thermal boundary layer above the surface of sample bodies in dimensions of 43 $\mathrm{mm} \times 40 \mathrm{~mm} \times 10 \mathrm{~mm}$ of beech wood in three different directions: longitudinal, radial, tangential cut. The temperatures of isothermal curves above the heated samples and coefficients of heat transfer $\alpha$ were determined by a quantitative analysis of holographic interferograms. The heat transfer coefficient a ranged within 4.6-7.4 W/m² $\mathrm{K}$. The simulation of heat transfer for the selected samples was prepared by the Fluent programme. Consequently, the measured values from the experiments were compared with the calculated values. There is a correlation between the measured and calculated values.
\end{abstract}

Keywords: temperature fields, beech wood, interferogram, holographic interferometry, heat transfer coefficient

SAŽETAK • Rad se bavi vizualizacijom toplinskih polja iznad površine uzorka tijekom zagrijavanja drva. Uz pomoć holografske interferometrije toplinska su polja beskontaktno vizualizirana nakon 0, 3, 7 i 15 minuta ili ranije u slučaju degradacije drva. U stvarnom vremenu zabilježeni su procesi u graničnome toplinskom sloju iznad površine uzorka od bukova drva dimenzija $43 \mathrm{~mm} \times 40 \mathrm{~mm} \times 10 \mathrm{~mm}$ u tri različita smjera: uzdužnome, radijalnome $i$ tangencijalnome. Temperature izotermalnih krivulja iznad zagrijanih uzoraka i koeficijenti prolaska topline a određeni su kvantitativnom analizom holografskih interferograma. Koeficijent prolaska topline a kretao se u rasponu od 4,6 do 7,4 W/ $\mathrm{m}^{2} \mathrm{~K}$. Simulacija prijenosa topline za odabrane uzorke napravljena je uz pomoć Fluent programa. Slijedom toga, vrijednosti izmjerene u istraživanju uspoređene su s izračunanim vrijednostima. Utvrđena je korelacija između izmjerenih i izračunanih vrijednosti.

Ključne riječi: temperaturna polja, bukovo drvo, interferogram, holografska interferometrija, koeficijent prolaska topline

\footnotetext{
Authors are associate professor, professor and researchers at Technical University in Zvolen, Faculty of Environmental and Manufacturing Technology, Department of Manufacturing and Automation Technology, Zvolen, Slovakia. ${ }^{2}$ Author is researcher at Technical University in Zvolen, Faculty of Wood Sciences and Technology, Institute of Foreign Languages, Zvolen, Slovakia.

Autori su izvanredni profesor, profesor i istraživači Tehničkog sveučilišta u Zvolenu, Fakultet za okolišnu i proizvodnu tehnologiju, Zavod za proizvodnju i automatizaciju, Zvolen, Slovačka. ${ }^{2}$ Autorica je istraživačica Tehničkog sveučilišta u Zvolenu, Fakultet drvnih znanosti i tehnologije, Institut za strane jezike, Zvolen, Slovačka.
} 


\section{INTRODUCTION}

\section{UVOD}

The topic of heat transfer by wood has been investigated for many years; however, it is still very current because its investigation can still widen the existing knowledge that can be used to observe heat leakage in wooden constructions, heat absorption for the detection of deformations and flaws, especially on the violin belly during production; to observe heat transfer in the floor heating, to verify fire and technical properties of wood, processes of its ignition, burning and thermic decomposition. Observation of temperature fields during wood heating widens the possibilities of wood utilisation beside its normal acoustic and aesthetic properties in the area of thermal insulation in the interiors and households.

The topic of heat transfer has been elaborated by many authors. Oumarou at al. (2014) studied the heat transfer in a numerical manner during thermal processing of wood at a high temperature. They also investigated 3D modelling of conjugated heat and mass transfer. Simo-Tagne et al. (2016) modelled heat and mass transfer during tropical wood drying. Kazi et al. (2015) calculated the heat transfer coefficient of liquid phloem pulp to monitor the quality of phloem and paper. They found out that the heat transfer was influenced by various properties of fibre such as fibre length, fibre flexibility, chemical and mechanical processing, variations of the fibre by different parts of a tree, as well as different methods used to produce cellulose. Kadem et al. (2011) modelled heat and mass transfer during thermal treatment of wood. They designed the simulation enabling the assessment of heat and mass transfer impact for the wood and surrounding air and provided a good insight into the complexity of transfer mechanisms. Zhang et al. (2013) experimentally investigated heat transfer mechanisms at flame spread along a horizontal surface of building materials (wood and extruded polystyrene surfaces). Duffy et al. (2011) calculated the characteristics of heat transfer and pressure loss for suspension of synthetic and cellulose fibres in an annular flow. Younsi et al. (2007) performed computer modelling of heat and mass transfer during high-temperature wood processing. Seoa et al. (2014) compared the heat transfer characteristics of wooden floorings according to their installations. Karabay et al. (2013) numerically investigated the flow and heat transfer inside a room for floor heating and wall heating. Liu et al. (2017) investigated the wood materials used for floor heating, Ding et al. (2016) investigated thermal degradation of beech wood, Deliiski et al. (2016) investigated modelling and energy consumption for heating, and Sinković et al. (2011) compared the physical properties of untreated and heat-treated beech. Many authors (Pavelek et al., 2009; Černecký et al., 2014; Sfarra et al., 2017) investigated the temperature fields by holographic interferometry.

In our research, the temperature fields above heated samples were observed. The aim was to obtain new information about wood properties, especially time dependencies, continuous change of temperature field and complete picture of a temperature field. The holographic interferometry should be used in visualizing temperature fields, enabling us to visualize temperature fields contact-free and to observe processes occurring in the thermal boundary layer in the interface of wood and surroundings.

\section{MATERIALS AND METHODS}

2. MATERIJALI I METODE

\subsection{Visualization and analysis of temperature fields}

\subsection{Vizualizacija i analiza temperaturnih polja}

The investigated processes during transfer are so complex that their mathematical analysis is possible only after several simplifications. Even though the sets of differential equations are achieved, they cannot be solved exactly in many cases. The transfer characteristics during thermal loading of wood are difficult to find mathematically; hence, they are often substituted by coefficients and criterion-based dependencies. Considering the complexity of the theoretical solution of the transfer phenomena by mathematical and modelling methods, it is always necessary to provide the prerequisite simplifications. The optic methods enable progress in solving the mentioned issues.

One of the possible applications of holographic interferometry is the visualization of temperature distribution above the sample body during observation of thermal loading of wood in different anatomic directions possibly for other sample bodies based on wood. The interference method enables to assess the observed phenomena in a quantitative way; moreover, it provides a complex picture of size and shape of thermal fields in the particular time while the measured values are not influenced by the reader. Another advantage of the method is the possibility to record a complete course from the beginning of heating of the sample to its ignition or flaming.

As most of the observed thermal fields are transparent environments, they are invisible to the human eye. It is necessary to change some physical parameters, such as temperature, to be able to observe these transparent substances. The thermal field above the sample body represents optical non-homogeneity. At the constant pressure, the relative gas density changes directly proportional to temperature changes. As the refractive index in an environment is the function of its density, the processes connected with the changes of temperature are characterized by the change of the refractive index.

The interference method is based on the identification of light wave phase change. The phase change determines the changes of refractive index. The environment with the higher temperature than the surroundings (reference environment) has a different density compared to it and therefore it also has a different refractive index. The determination of the refractive index in different places in the environment enables to state its density and, thereafter, its temperature. 
The formula (1) (Pavelek and Štětina, 1997; Brodnianská and Pivarčiová, 2018) was used to calculate the final functional dependence of temperature on parameters of the ambient environment, sample body length, wavelength (it is included in the constant) and on the number of dark fringes from the place of the homogenous environment:

Where

$$
T(x, y)=\frac{T_{\infty}}{1-0.805 \cdot \frac{T_{\infty}}{l \cdot p_{\infty}} \cdot\left(s-\frac{1}{2}\right)}
$$

$T(x, y)$ - temperature distribution $(\mathrm{K})$,

$T_{\infty}$ - air temperature in the reference area $(\mathrm{K})$,

$p_{\infty}-$ pressure in the given space $(\mathrm{Pa})$,

$s$ - order of interference (-),

$l$ - model length, along which laser rays verge (m).

Figure 1a shows a square cut through individual isotherms in a specified distance $x$, where the values of temperatures $T(x, y)$ are calculated according to the relation.

An example of the assessment of the temperature profile above heated body is shown in Figure 1b, where the detailed cut-out of the holographic interferogram can be seen. The interferogram shows interference fringes position and distribution of interference orders of the particular cut-out, which transfers the individual colours into the black and white scale. 0 refers to black colour, 255 refers to white colour and then there are the shades of grey. The cut enables specifying the middle position of interference fringes denoted by $\mathrm{y}$ axis, while s relates to interference orders (Figure 1b).

In the analysis, the calculation of heat transfer from the temperature derivations was used. The value of the local coefficient of heat transfer $\alpha_{x}$ depends on many factors, such as flow velocity, surface form, position of the sample body and temperature difference between the surface and the ambient environment. The typical shape of the temperature profile in a thermal boundary layer with the local thickness $\delta_{\mathrm{x}}$ and local temperature on the sample surface $T_{\mathrm{x}}$ higher than the temperature of the surrounds $T_{\infty}$ is illustrated in Figure 2.
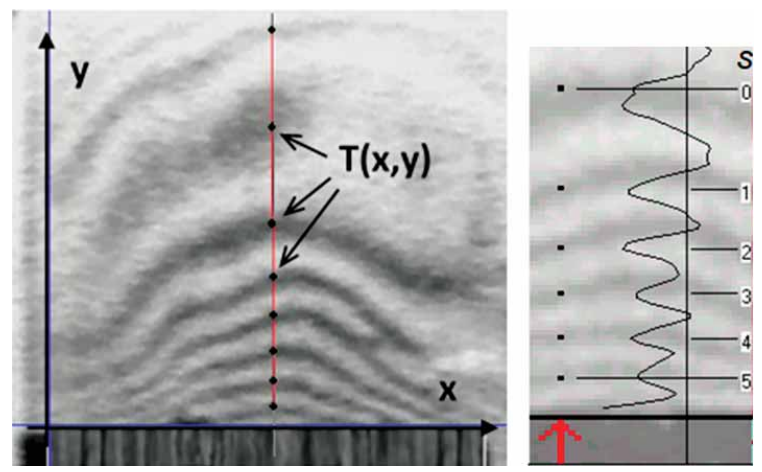

Figure 1 a) Orientation of axes $x$ and $y$ in a recorded interferogram, b) Defining the positions of interference fringes minima and distribution of interference orders $s$ Slika 1. a) Orijentacija osi $x$ i $y$ u snimljenom interferogramu, b) definiranje položaja najmanjih rubova interferencije i raspodjele interferencijskih naloga $s$

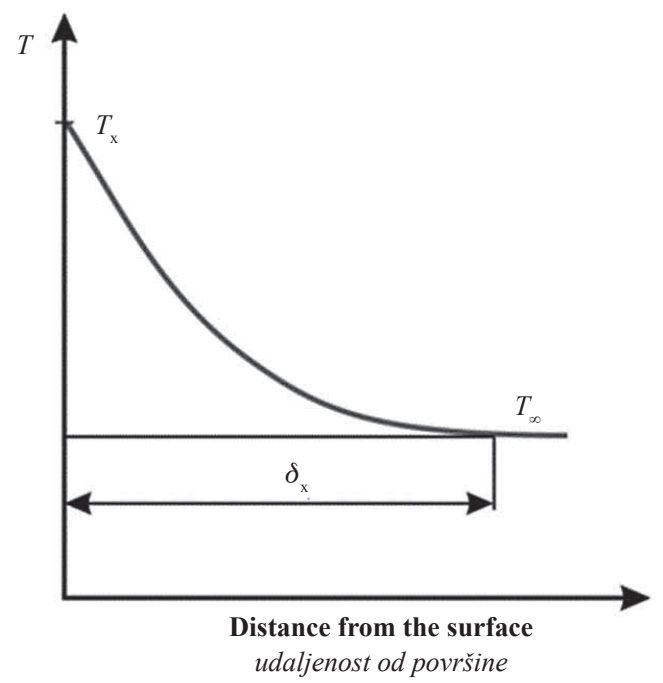

Figure 2 Temperature profile $\left(\delta_{\mathrm{x}}-\right.$ local thickness of thermal boundary layer, $T_{\mathrm{x}}$ - local temperature on sample surface, $T_{\infty}$ - temperature of the surrounding)

Slika 2. Temperaturni profil $\left(\delta_{\mathrm{x}}-\right.$ lokalna debljina toplinskoga rubnog sloja, $T_{\mathrm{x}}$ - lokalna temperatura na površini uzorka, $T_{\infty}$ - temperatura okoline)

The local coefficient of heat transfer can be expressed by the equation (Brodnianská and Pivarčiová, 2018):

Where

$$
\alpha_{\mathrm{x}}=-\lambda_{\mathrm{t}}\left(\frac{d T}{d y}\right)_{\mathrm{x}} \frac{1}{T_{\mathrm{x}}-T_{\infty}}
$$

$\alpha_{\mathrm{x}}$-local coefficient of heat transfer $\left(\mathrm{W} / \mathrm{m}^{2} \mathrm{~K}\right)$,

$\lambda_{\mathrm{t}}^{\mathrm{x}}$ - coefficient of heat conductivity of the air $(\mathrm{W} / \mathrm{mK})$,

$T_{x}$-area temperature of the local point $x(\mathrm{~K})$,

$T_{\infty}$ - temperature of the surroundings $(\mathrm{K})$, $\mathrm{d} T / \mathrm{d} y$ - temperature derivation.

\subsection{Experimental set-up}

\subsection{Postavljanje eksperimenta}

To measure the heat transfer in three basic anatomic directions (radial, tangential, longitudinal), sample bodies of beech were used in the dimensions of 43 $\mathrm{mm} \times 40 \mathrm{~mm} \times 10 \mathrm{~mm}$. Considering the aim of the experiment, which was to monitor the heat transfer and not the thermal degradation, two electric infra-red board heating devices of the total power input of 300 $\mathrm{W}$ with the option of manual adjustment of the heat output ranging from $15-100 \%$ were used as the heat source. The output restriction was adjusted to $75 \%$. The distance of the infra-red heating devices from the shield AI with a square opening of $20 \mathrm{~mm} \times 20 \mathrm{~mm}$ was $100 \mathrm{~mm}$. The distance of the sample $\mathrm{S}$ from the shield was $18 \mathrm{~mm}$ (Figure 3 ).

Holographic interferograms of temperature field above the heated sample body were recorded at the temperature of the surrounding $298 \mathrm{~K}\left(25^{\circ} \mathrm{C}\right)$ and pressure of $98100 \mathrm{~Pa}$. Holograms were recorded when Mach-Zehnder interferometer was set up for the infinite width of interference fringes in the real time. During the experiment, the distribution of temperature field above the heated sample was recorded after the time periods set in advance ( 3 minutes, 7 minutes, 15 


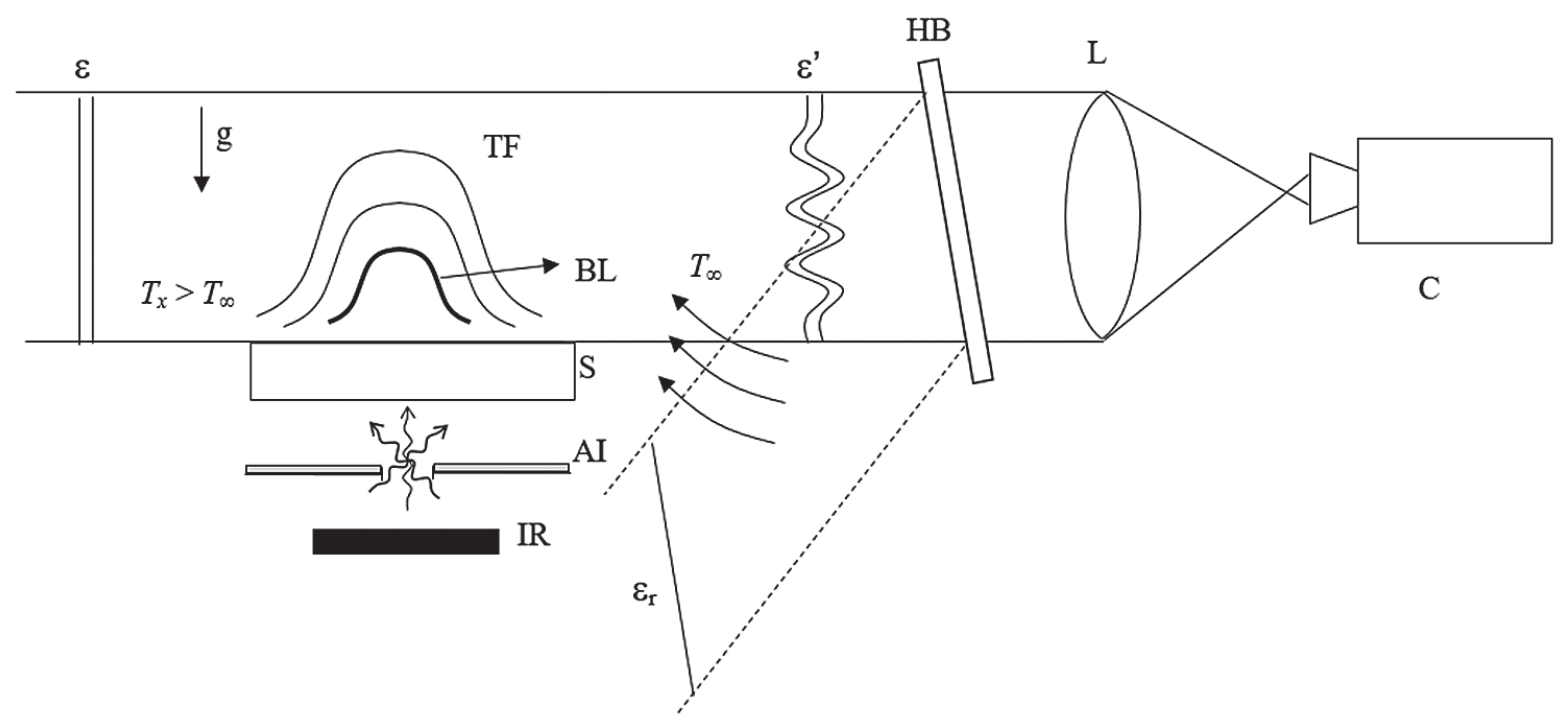

Figure 3 Heating up the sample body - Experiment scheme (TF - thermal field, BL - boundary layer, S - sample, AI - aperture with insulation, IR - infrared radiator, $\varepsilon$-wavelength, $\varepsilon$ ' - light wave after the transfer through the thermal field, $e_{\mathrm{r}}$ - reference light wave, $\mathrm{HB}$ - holographic board, $\mathrm{L}$ - lens, $\mathrm{C}$ - camera, $g$ - gravitational acceleration, $T_{\mathrm{x}}-$ local temperature on the sample surface at the point $\mathrm{x}, T_{\infty}$ - surrounding temperature)

Slika 3. Zagrijavanje uzorka - shema eksperimenta (TF - termalno polje, BL - granični sloj, S - uzorak, AI - otvor s izolacijom, IC - infracrveni radijator, $\varepsilon$ - valna duljina, $\varepsilon^{\prime}-$ svjetlosni val nakon prijenosa kroz termalno polje, $e_{\mathrm{r}}-$ referentni svjetlosni val, HB - holografična ploča, L - leća, C - kamera, $g$ - gravitacijsko ubrzanje, $T_{\mathrm{x}}$ - lokalna temperatura na površini uzorka, na mjestu x, $T_{\infty}$ - temperatura okoline)

minutes and or earlier if degradation occurred). During the experiment, the area above the upper side of the sample body was observed because that expresses the best three kinds of heat (convection, radiation, and conduction), thermal and physical properties of the sample body and meanwhile its resistance to destruction.

\section{RESULTS AND DISCUSSION 3. REZULTATI I RASPRAVA}

The method of holographic interferometry in the real time was used to observe temperature fields above the sample bodies from beech wood in three different directions (longitudinal, tangential and radial). The method enabled the presentation of a complete concept and illustration of the size and shape of the temperature field in the particular time via the recorded field of the refractory index of the examined environment, which consequently enabled the analysis and interpretation of the observed phenomenon. The method did not require the entry of the mechanical recorder or scanner into the measured space. Another advantage of the method is the possibility to record a complete time change from the beginning of heating till the ignition.

The course of the experiment was of a dynamic character; individual images changed rather quickly. When the sample bodies are loaded, the heat transfer occurs; the thermal boundary layer appears in close proximity above the heated sample, where interference fringes might be observed.

Quantitative analysis of holographic interferograms images depicts the shape of the temperature fields above the heated sample and mutual influencing of cold and hot air. Interferometry enabled recording of a complete temperature field in the monitored area and recording of instant processes and development of the boundary layer. The demonstration of holographic interferograms of temperature fields above the heated sample is given in Figure 4.

The images show a steady increase in the width of the boundary layer. In the more distant area from the sample body, the chaotic distribution of interference fringes caused by mixing of cold and warm air occurs. The interference fringes represent the isothermal curves of the temperature field. The images show the individual interference fringes, which are clearly defined due to the change in the refractory index. It is caused by the fact that the sample body is also gradually heated on the top side. The higher the surface temperature is, the more fringes occur. It is possible to calculate the temperatures for the individual fringes.

At the images of temperature fields, the development of the thermal boundary layer, which gradually widens in the vertical direction above the surface of the tested sample, can be observed. Widening of the boundary layer is caused by decreasing the temperature gradient on the surface and decreasing of the heat transfer parameters. The interaction of cold and warm air can also be seen in the images (Figure 6). The possibility to observe the mutual interaction of the thermal boundary layers is a considerable advantage of the holographic interferometry.

During experiments, it was possible to observe the formation of sequences of typical shapes of interference fringes. Individual types are shown in Figure 5.

Holograms with closed curves are not usable for assessments (Figure 5g), which were recorded immedi- 


\begin{tabular}{|c|c|c|c|c|}
\hline $\begin{array}{c}\text { Beech } \\
\text { Bukovina }\end{array}$ & $\begin{array}{c}\text { BBefore experiment } \\
\text { (without heating) } \\
\text { Prije eksperimenta } \\
\text { (bez zagrijavanja) }\end{array}$ & $\begin{array}{l}\text { During experiment } \\
\text { (start of heating } \\
\mathbf{- 3} \text { min) } \\
\text { Tijekom eksperimenta } \\
\text { (početak zagrijavanja, } \\
3 \text { min) }\end{array}$ & $\begin{array}{l}\text { During experiment } \\
\text { (heating - } 7 \text { min) } \\
\text { Tijekom eksperimenta } \\
\text { (zagrijavanje, } 7 \text { min) }\end{array}$ & $\begin{array}{c}\text { End of experiment } \\
\text { (glowing combustion } \\
\text { or burnt through } \mathbf{- 8}, \\
\mathbf{1 0}, \mathbf{1 5} \text { min) } \\
\text { Kraj eksperimenta } \\
\text { (užareno izgaranje ili } \\
\text { izgaranje, } 8,10,15 \mathrm{~min} \text { ) }\end{array}$ \\
\hline $\begin{array}{l}\text { Longitudinal } \\
\text { direction } \\
\text { Longitudinalni } \\
\text { smjer }\end{array}$ & +2 & & & 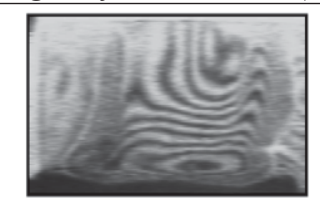 \\
\hline $\begin{array}{l}\text { Radial direction } \\
\text { Radijalni smjer }\end{array}$ & 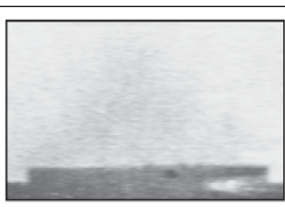 & & & \\
\hline $\begin{array}{l}\text { Tangential } \\
\text { direction } \\
\text { Tangencijalni } \\
\text { smjer }\end{array}$ & 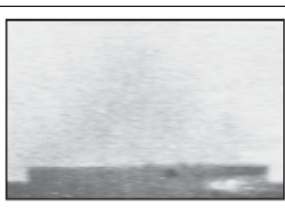 & & & \\
\hline
\end{tabular}

Figure 4 Holographic interferograms of temperature fields for horizontal wood sample - beech recorded by interferometer set for an infinite width of fringes

Slika 4. Holografski interferogrami temperaturnih polja vodoravnog uzorka drva - bukovina zabilježena interferometrom za beskonačnu širinu rubova

ately before the sample burned through. The images that were formed are rather complicated; they contain closed curves and there are too thick interference fringes in the holograms that are impossible to assess quantitatively.

Holograms with the chimney effect gained after burning through were equally impossible to assess (Figure 5h). The temperature field has its characteristic shape given by the escaping combustible gases and hot exhaust gases that spread into sides closely above the sample surface. It can be seen that originally almost horizontal shape of fringes changes into vertical. The fringes have almost a parallel course, especially in the upper part.

During the experiment, it was found that temperatures tend to change under the influence of the disturbances of the ambient environment. The temperature difference was small and changed its position impacted by fluxes of cold air. The values closely above the sample surface are the most objective; the bigger the distance from the sample surface, the stronger is the impact of the surrounding.

Considering the fact that the experiments were performed in a common laboratory, the images show that the shape of interference fringes is influenced by surrounding conditions in the laboratory such as:

- Local natural convection in the measured space above the sample body, caused by mixing warmer air that comes from the sample body and colder air that exists in the surrounding environment, occurs at a certain distance above the sample bodies where the temperature gradient is lower. This caused the formation of bubbles (Figure 5d). Closely above the sample, there was a big temperature gradient. In places where the temperature gradient decreased, a bubble was formed. During observation, there was opening and closing of the bubble, which was caused by natural convection. The initial stage before a bubble was called "tongues" (Figure 5c)

- Figure 5f shows recorded air convection in the laboratory - in places where the experiments were performed, it was warmer than in the more distant places - Natural convection occurred during the heating of samples. Cold and warm air mixed and the warm air was pushed upward (Figure 5e), which caused the disturbance in the regular shape of interference image (Figure 5e). It is possible to observe two areas in the holograms (Figure 6): the area of the cold air impact, where it is impossible to assess the interference order, and the area for the quantitative analysis, where the interference order can be identified.

- In the area close to the place of ignition, shortly before burning through, the interference fringes, which cannot be used to assess the temperature, appeared. These holograms do not fit into the system of assessment and cannot be assessed. (Figure $5 \mathrm{~g}, \mathrm{~h}$ ).

Quantitative analysis of the recorded images of the holographic interferograms is a time consuming and expertise-based process. To manage this work effectively, specialised software, designed at our workplace, was used. The programme enables to calculate the temperatures for individual orders using Eq. 1. Meanwhile, algorithms are also implemented to calculate the values of coefficients of heat transfer $\alpha$ according to Eq. 2.

Observing the holograms, it was found out that in most cases it is not clear where the highest temperature 


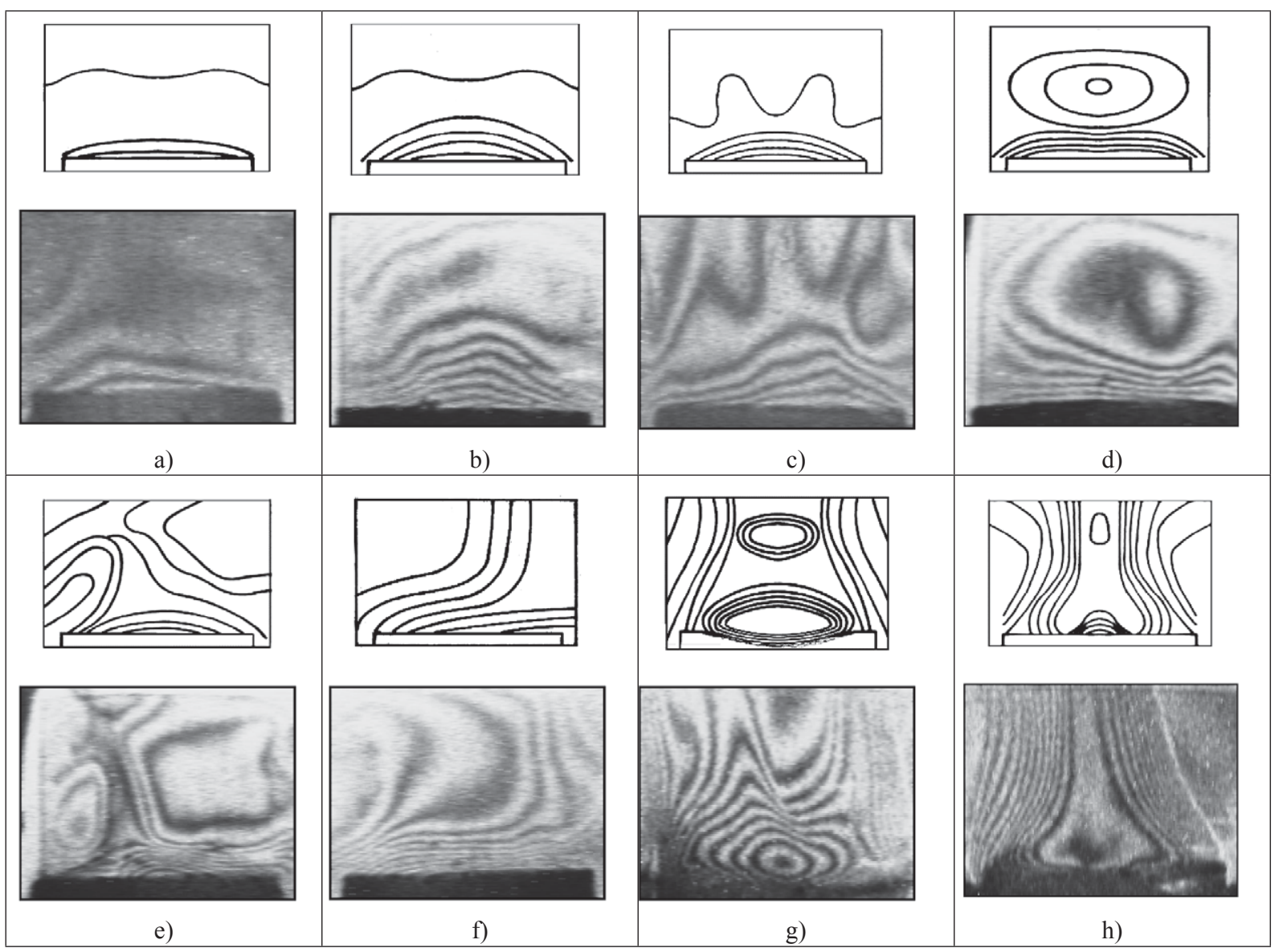

Figure 5 Typical shapes of temperature fields during heating of wooden samples: a) a small number of interference fringes the start of heating, b) a bigger number of interference fringes - heating, c) tongues - initial state before a bubble, d) bubbles - an influence of the local natural convection above the sample, e) additional interference fringes - not keeping the dimensions of the sample body, f) waves - the influence of convection, g) complicated images with closed curves - immediately before burning through a sample, h) a chimney - after burning through the sample

Slika 5. Tipični oblici temperaturnih polja tijekom zagrijavanja uzoraka drva: a) mali broj interferencijskih granica - početak zagrijavanja, b) veći broj interferencijskih granica - zagrijavanje, c) jezici - početno stanje prije mjehurića, d) mjehurići utjecaj lokalne prirodne konvekcije iznad uzorka, e) dodatne granice interferencije - bez zadržavanja dimenzija tijela uzorka, f) valovi - utjecaj konvekcije, g) komplicirane slike sa zatvorenim zavojima - neposredno prije izgaranja kroz uzorak, h) dimnjak - nakon izgaranja kroz uzorak

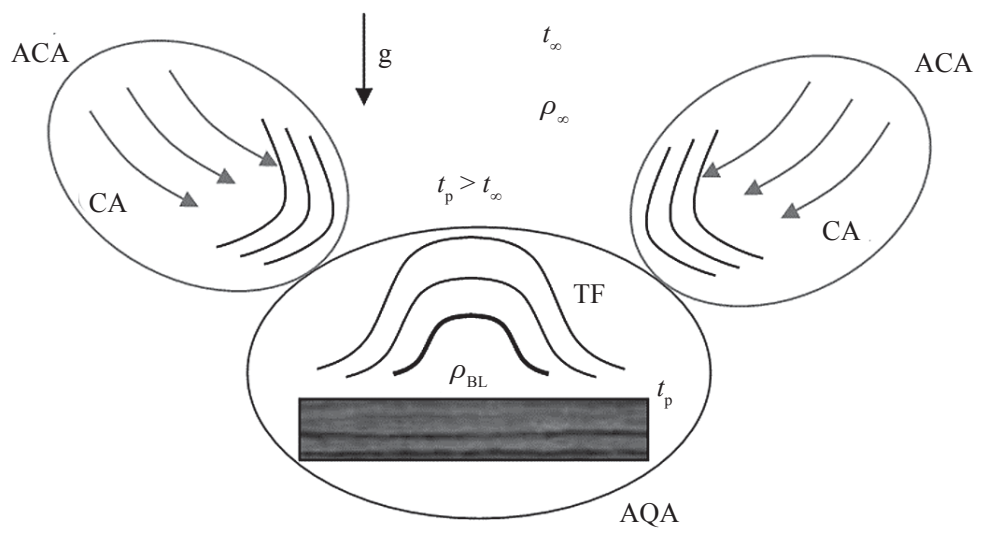

Figure 6 Airflow above sample (TF - temperature field, $\mathrm{BL}$ - boundary layer, $g$ - gravitation acceleration, $t_{\mathrm{p}}-$ sample surface temperature, $t_{\infty}$ - surrounding air temperature, $\rho_{\mathrm{BL}}$ density of the boundary layer, $\rho_{\infty}-$ density of the surrounding air, CA - ambient cold air flow, AQA - the area for the quuantitative analysis, ACA - the area of the cold air impact)

Slika 6. Protok zraka iznad uzorka (TF - temperaturno polje, BL - granični sloj, $g$ - gravitacijsko ubrzanje, $t_{\mathrm{p}}$ - temperatura površine uzorka, $t_{\infty}$ - temperatura okolnog zraka, $\rho_{\mathrm{BL}}$ gustoća graničnog sloja, $\rho_{\infty}$ - gustoća okolnog zraka, CA - protok hladnog zraka, AQA - područje za kvantitativnu analizu, ACA - područje utjecaja hladnog zraka) 


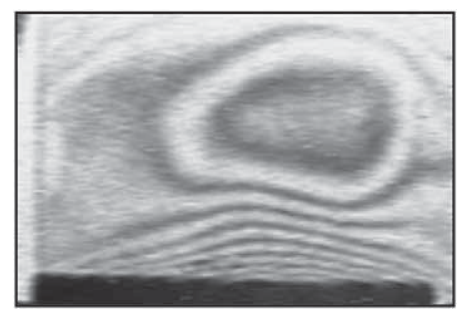

a)

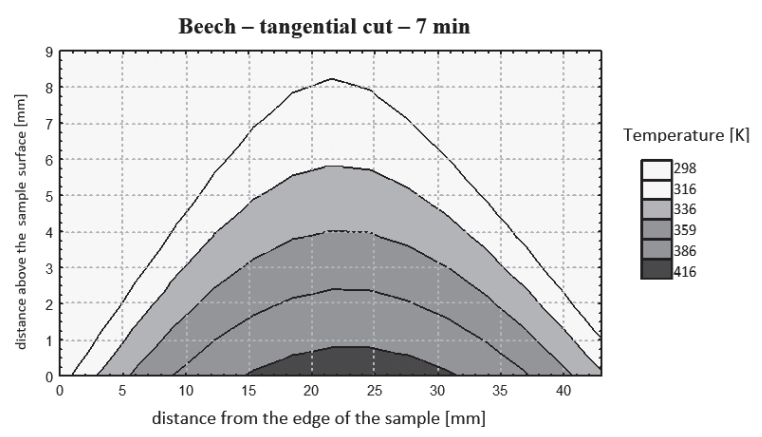

b)

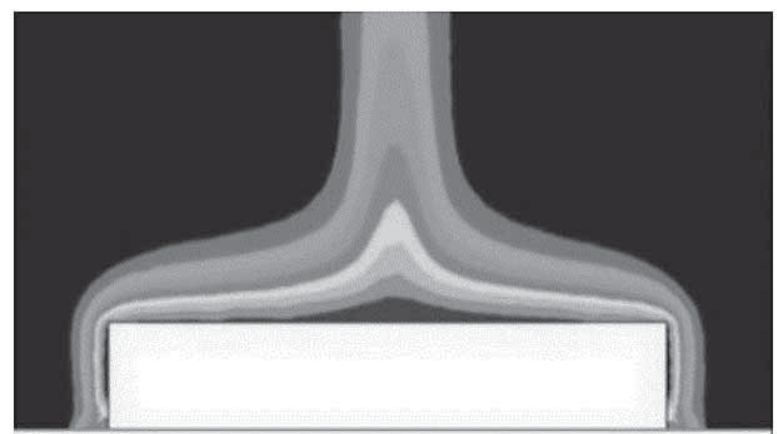

c)

Figure 7 Temperature fields above the heated sample: a) Experimental holographic interferogram, b) Analytical illustration of the temperature calculated by Eq. 1 depending on distance above the sample and from the edge of the sample, c) CFD simulation

Slika 7. Temperaturna polja iznad zagrijanog uzorka: a) eksperimentalni holografski interferogram, b) analitički prikaz temperature izračunane prema formuli (1) u ovisnosti o udaljenosti od površine i ruba uzorka, c) CFD simulacija

is because the number of fringes is the same in the centre and at the edges of the sample, which means that the temperatures are the same but at different distances above the sample body. This is caused by the fact that the dimensions of the sample were rather small, and the temperature spread across the complete surface of the sample body. The heat transfer was influenced by the wood species structure (e.g. density), dimensions of the sample body, and ambient surrounding impacts.

CFD simulation of heat transfer was conducted by the commercial programme Fluent to enable the comparison of the temperature fields from the holographic interferograms achieved by the experiment.

Figure 7 shows the change of the temperature fields above the heated sample. The temperatures of the isothermal curves (Figure 7a) were expressed by the quantitative analysis of holographic interferograms by Eq. 1. Figure $7 \mathrm{~b}$ shows the graph illustrating the tem- perature change depending on the distance and position on the sample body. Figure 7c shows simulation of the temperature field via Fluent programme.

The values of interference orders $\mathrm{s}$ and the distances corresponding to individual interference orders were determined by the analysis of holographic interferograms with a great emphasis on the accuracy of reading interference fringes. To calculate $T$ temperature, Eq. 1 was used and the entered input parameters were: temperature of the surrounding $T_{\infty}=25^{\circ} \mathrm{C}(298$ $\mathrm{K})$, pressure of the surrounding $p_{\infty}=98100 \mathrm{~Pa}$, the ordinal number of the interference order $s=0,1, \ldots$ (Figure $1 \mathrm{~b}$ ), sample length $l=0.043 \mathrm{~m}$. Further processing was carried out by Statistica program and the graphical illustration of the temperature progress depending on the height $\mathrm{y}$ above the sample and distance $\mathrm{x}$ from the edge of the sample (Figure 7b). The identical geometrical and boundary conditions: the temperature of the surrounding $25^{\circ} \mathrm{C}(298 \mathrm{~K})$ and pressure of $98100 \mathrm{~Pa}$ were used for the CFD simulation (Figure 7c) by the program Fluent and in the experiment.

The calculation network (of the triangle elementary type) was generated with the optimum number of calculation points. The simulation analyses for boundary conditions were performed as follows: The viscosity model was chosen ,laminar", the density of the air was calculated for the ideal gas. The interface fringes above the heated sample correlate with the outline of the temperature fields achieved by simulation. Figure 8 shows the three-dimensional graphs of the analytical illustration of the dependence of temperature, direction, and distance above the sample.

Figure 8 shows that the highest temperature during heating the sample in the longitudinal direction was $493 \mathrm{~K}$ at $1.3 \mathrm{~mm}$ above the sample, in the radial direction the highest temperature was $450 \mathrm{~K}$ at $0.3 \mathrm{~mm}$ and

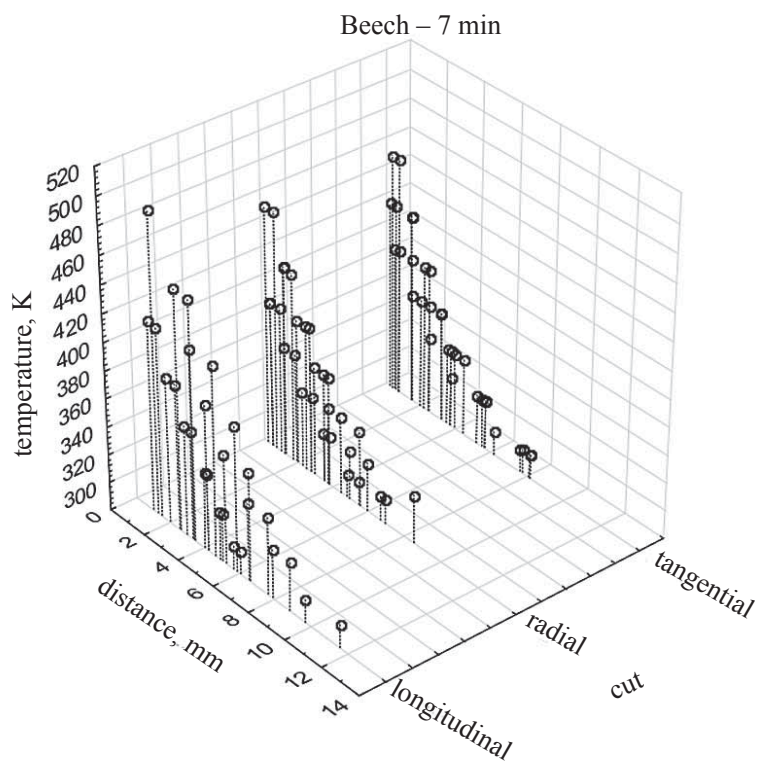

Figure 8 Analytical illustration of the temperature calculated by Eq. 1 depending on direction and distance above the sample

Slika 8. Analitička ilustracija temperature izračunane prema formuli (1) u ovisnosti o smjeru i udaljenosti od površine uzorka 


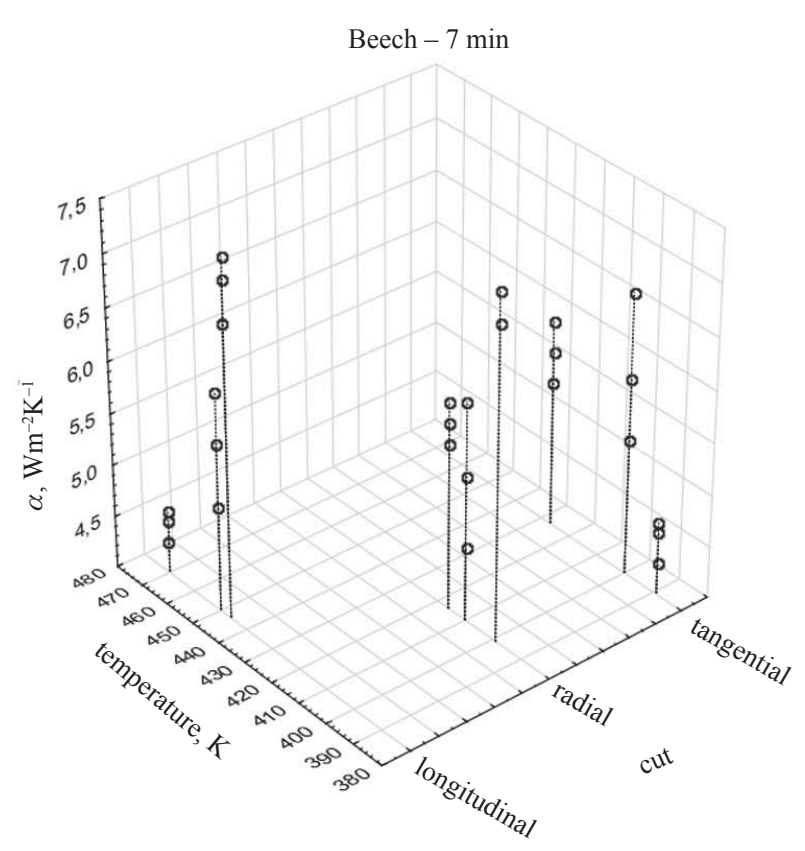

Figure 9 Heat transfer coefficient $\alpha$ calculated by Eq. 2 depending on temperature calculated by Eq. 1 and direction Slika 9. Koeficijent prijenosa topline $\alpha$ izračunan prema formuli (2) u ovisnosti o temperaturi izračunanoj prema formuli (1) i smjeru

in the tangential direction it was $450 \mathrm{~K}$ at $0.4 \mathrm{~mm}$. Figure 9 shows the graphically illustrated local coefficient of heat transfer $\alpha$ calculated from the holographic interferograms according to Eq. 2. For example to calculate the local heat transfer coefficient $\alpha=5.72 \mathrm{~W} / \mathrm{m}^{2} \mathrm{~K}$, the following input values were used: table value of the heat conductivity coefficient for the air on the sample body surface $\lambda_{\mathrm{t}}=0.02854$ at temperature $T_{\mathrm{x}}=342 \mathrm{~K}$ of the surface at the local point $\mathrm{x}=10 \mathrm{~mm}$, calculated by Eq. 1, at surrounding temperature $T_{\infty}=298 \mathrm{~K}$. Temperature derivation $\mathrm{d} T / \mathrm{d} y=-8816.51$ was entered as the ratio of temperature differences $(359-386 \mathrm{~K})$ and distances of two interference fringes $(3 \mathrm{~mm})$ at the point $\mathrm{x}$ above the sample surface.

Figure 9 shows that the values of the heat transfer coefficients $\alpha$ within the range of $4.6-7.4 \mathrm{~W} / \mathrm{m}^{2} \mathrm{~K}$. Heat transfer in woods is influenced by a number of factors, the most influential being presented by the anatomic structure of the wood, density and moisture content of wood. Scattering of the calculated values of heat transfer coefficient $\alpha$ also depends on the method of measuring and outer conditions during the individual measurements.

\section{CONCLUSIONS}

\section{ZAKLJUČAK}

Within the experiment, the temperature fields during thermal loading of beech samples in various time intervals and various distances from the surface were visualized. The data on temperature fields during thermal loading of beech samples were obtained. At the same time, the information was obtained about wood behaviour in the process of thermal loading in dependence on temperature and temperature gradients which can be recorded by interferometric methods. The various shapes of interference fringes typical for the thermal loading of wood were recorded.

The local coefficients of heat transfer $\alpha$ for three directions were calculated from the holographic images. The recorded and assessed data resulted in the value of heat transfer coefficient $\alpha$ which ranged within 4.6 $-7.4 \mathrm{~W} / \mathrm{m}^{2} \mathrm{~K}$.

Using holographic interferometry, the method for calculating the heat transfer coefficient alfa was found. Further investigation is required to polish up the method of determination of the temperature derivation on the sample/body surface, which will enable stating the alfa coefficient more precisely; e.g. to substitute the temperature progress in the boundary layer by a mathematical procedure.

In our research, the temperature field was observed as a whole, rather than local changes that can be measured by thermo-couples. That enabled us to record a dynamic process - heat exchange above the samples, which can be used aptly e.g. to choose the material suitable for floor heating.

Further research may focus on temperature fields from the samples of other wood-based materials (such as chipboard, plywood), samples with wood joints, samples with treated surface, samples with flame retardant treatment, the use of radiant heat, etc.

\section{Acknowledgements - Zahvala}

The paper was elaborated with the support of the Ministry of Education, Science, Research and Sports of the Slovak Republic within grant project VEGA 1/0315/17: Research of applicable properties of thermally modified wood in interaction phenomena of matching process with optimal surface prediction and VEGA 1/0086/18: Researching temperature fields in a set of shaped heat transfer surfaces.

\section{REFERENCES}

5. LITERATURA

1. Brodnianská, Z.; Pivarčiová, E., 2018: Heat and Mass Transfer (in Slovak). Publisher of Technical University in Zvolen, 2018., 255 p.

2. Cernecky, J.; Koniar, J.; Brodnianska, Z., 2014: The effect of heat transfer area roughness on heat transfer enhancement by forced convection. Journal of Heat Transfer, 136 (4): 4025920. doi: 10.1115/1.4025920.

3. Deliiski, N.; Trichkov, N.; Angelski, D.; Dzurenda, L., 2016: Modeling and Energy Consumption of Unilateral Heating Process of Flat Wood Details. Drvna industrija, 67 (4):381-391.https://doi.org/10.5552/drind.2016.1518.

4. Ding, Z.; Ezekoye, O. A.; Lu, S.; Wang, Ch., 2016: Thermal degradation of beech wood with thermogravimetry / Fourier transform infrared analysis. Energy Conversion and Management, 120: 370-377.

https://doi.org/10.1016/j.enconman.2016.05.007.

5. Duffy, G. G.; Kazi, S. N.; Chen, X. D., 2011: Heat transfer and pressure drop characteristics of suspensions of synthetic and wood pulp fibres in annular flow. Applied Thermal Engineering, 31 (14.15): 2971.2980. https://doi.org/10.1016/j.applthermaleng.2011.05.028. 
...... Pivarčiová, Barcík, Štefková, Škultéty: Investigation of Temperature Fields in the Air...

6. Kadem, S.; Lachemet, A.; Younsi, R.; Kocaefe, D., 2011: 3D-Transient modeling of heat and mass transfer during heat treatment of wood. International Communications in Heat and Mass Transfer, 38 (6): 717-722.

https://doi.org/10.1016/j.icheatmasstransfer.2011.03.026.

7. Karabay, H.; Arıc1, M.; Sandık, M., 2013: A numerical investigation of fluid flow and heat transfer inside a room for floor heating and wall heating systems. Energy and Buildings, 67: 471-478.

https://doi.org/10.1016/j.enbuild.2013.08.037.

8. Kazi, S. N.; Duffy, G. G.; Chen, X. D., 2015: Heat transfer coefficient of flowing wood pulp fibre suspensions to monitor fibre and paper quality. Applied Thermal Engineering, 78: 172-184. https://doi.org/10.1016/j.applthermaleng.2014.11.072.

9. Liu, C.; Luo, R.; Zhou, S.; Du, G., 2017: The Construction of Heat Storage Performance Testing Method of Wood Materials used for Floor Heating. Procedia Engineering, 205: 3804-3810. https://doi.org/10.1016/j.proeng.2017.10.116.

10. Oumarou, N.; Kocaefe, D.; Kocaefe, Z., 2014: 3D-modelling of conjugate heat and mass transfers: Effects of storage conditions and species on wood high temperature treatment. International Journal of Heat and Mass Transfer, 79: 945-953. https://doi.org/10.1016/j.ijheatmasstransfer.2014.08.086.

11. Pavelek, M.; Janotková, E.; Pavelek, T., 2009: Applying interferometry in researching convection heat transfer from panel radiators. Journal of Flow Visualization and Image Processing, 16 (2): 159-181. https://doi.org/10.1615/JFlowVisImageProc.v16.i2.40.

12. Pavelek, M.; Štětina, J., 1997: Experimentální metody v technice prostředí. VUT Brno, 215 p.

13. Seoa, J.; Parka, Z.; Kima, J.; Kima, S.; Kimc, J. T., 2014: Comparison of thermal transfer characteristics of wood flooring according to the installation method. Energy and Buildings, 70: 422-426.

https://doi.org/10.1016/j.enbuild.2013.11.085.
14. Sfarra, S.; Theodorakeas, P.; Cernecky, J.; Pivarčiová, E.; Perilli, S.; Koui, M., 2017: Inspecting Marquetries at Different Wavelengths: The Preliminary Numerical Approach as Aid for a Wide-Range of Non-destructive Tests. Journal of nondestructive evaluation, 36 (1): 2-20. https://doi.org/10.1007/s10921-016-0384-2.

15. Simo-Tagne, M.; Rémond, R.; Rogaume, Z.; Zoulalian, A.; Bonoma, B., 2016: Modeling of coupled heat and mass transfer during drying of tropical woods. International Journal of Thermal Sciences, 109: 299-308. https://doi.org/10.1016/j.ijthermalsci.2016.06.012.

16. Sinković, T.; Govorčin, S.; Sedlar, T., 2011: Comparison of Physical Properties of Untreated and Heat Treated Beech and Hornbeam. Drvna industrija, 62 (4): 283-290. https://doi.org/10.5552/drind.2011.1118.

17. Younsi, R.; Kocaefe, D.; Poncsak, S.; Kocaefe, Y., 2007: Computational modelling of heat and mass transfer during the high-temperature heat treatment of wood. Applied Thermal Engineering, 27 (8-9): 1424-1431. https://doi.org/10.1016/j.applthermaleng.2006.10.025.

18. Zhang, Y.; Sun, J. H.; Huang, X. J.; Chen, X. F., 2013: Heat transfer mechanisms in horizontal flame spread over wood and extruded polystyrene surfaces. International Journal of Heat and Mass Transfer, 61: 28-34. https://doi.org/10.1016/j.ijheatmasstransfer.2013.01.069.

\section{Corresponding address:}

Assoc. Prof. ELENA PIVARČIOVÁ

Technical University in Zvolen

Faculty of Environmental and Manufacturing

Technology

Department of Manufacturing and Automation

Technology

Študentská 26, 96053 Zvolen, SLOVAKIA

e-mail: pivarciova@tuzvo.sk 